\title{
An Empirical Study on Corpus- based Translation Teaching for Non English Majors
}

\author{
Ke Xixiang \\ Foreign Language Schools \\ Wuhan Textile University \\ Wuhan, China \\ e-mail: tzh998998@hotmail.com
}

\author{
Tan Zhenghua \\ Foreign Language Schools \\ Jianghan University \\ Wuhan, China \\ e-mail: 1753270552@qq.com
}

\begin{abstract}
Translation is a significant activity in crosscultural and cross-linguistic communication. Translators, as native speakers, are prone to make errors in translation between target language and source language due to both lack of a frame of reference and the general trend of diction based on first-language-oriented input. Thus corpora are used in the study of language contrast and translation studies. Many relevant researches emerge while the study on corpus application in translation teaching for non English majors is not widely available. This paper attempts to study the effect of corpus on translation teaching for non English majors via experimental method and come up with solutions to practical problems in the translation teaching experiment. Conclusion: corpus-based translation teaching model will promote the translation competence, thus significantly improve English Comprehensive application ability.
\end{abstract}

Keywords-translation teaching; learners role; translation process; corpus;application

\section{INTRODUCTION}

The corpus is a collection of texts in accordance with the standards of design that are often used in the media and works, such as Corpus of Contemporary American English COCA and National Corpus British.

In the practice of translation, corpus can be used to strengthen cultural awareness, improve the ability of language expression and provide a reference tool and a research platform for teachers and students; offer the searching function for the traditional translation teaching and learning to confirm language accuracy, thus improve translation performance and arouse students' learning interest in translation; as a tool, corpus can enhance the consciousness to apply corpus and deepen understanding of translation; to cultivate qualified professionals. Students' much participation and frequent interaction between teachers and students help to cultivate a harmonious relationship between teachers and students.

All the researches and relevant conclusions concerning language phenomena depend on examination of the practical application of language and location of the rule of language usage and on a lot of language facts that can be used for comprehensive analysis. English corpus satisfies the requirement with real language materials and data. Corpus can be employed to check whether the term or collocation match the language specification, judge whether the solution of the concrete translation problems is reasonable or not, confirm validation or authenticity of translation or the effect of corpus on the translation teaching thus providing us a new method and a new way of thinking. In short, corpus can be used as an instrument to cultivate translation talents. The development of global economy calls for qualified translation talents. It's necessary and urgent to foster translation skills of non English majors.

\section{LITERATURE REVIEW}

Corpus-based translation studies was initiated by Baker (1995)[1], who described in detail in the theory value, practical significance and the concrete path of corpora in translation studies. Since 1995, Mona Baker and his team began to build the world's first translation corpus, namely, Translational English Corpus and carry out a series of corpus-based translation studies, such as the study of translation universals (Baker 1995, Baker 1998[2]; Laviosa 1998a 1998b[3]; Kenny, 1998, 2001[4]), the study of translator's style and the study of translation norms (Kenny 2001[4]). Foreign relevant research reflects in the following aspects: (1) Differences between target text and source text; (2) The impact of specific differences in language and style on target text; (3) Stylistic preferences for specific translator will affect the purpose of discourse ; (4) Study on translation teaching based on corpus(Bowker, 2001)[5].

In addition to the study of translation universals via corpus, corpus in translation research (Wang Kefei 2002,2004,2012[6]; Luo 2005[7] ), translation norms (Hu Kaibao2007[8]), translation method, translation criticism, translation teaching and interpretation (Wang Kefei 2002,2004, 2012) Zhang Meifang2002 [9], Xu Wensheng, Zhang Bairan2006[10], $\mathrm{Hu}$ Xianyao2009[11]) are implemented.

The domestic research mainly focuses on the following aspects: (1) Translation comparison; (2) Translator's style; (3) Comparison of language structure; (4) The translation of specific words; (5) The study of translation teaching. In previous research, the application of corpus in translation teaching is still in the early stages. And there is little empirical study on translation teaching based on corpus for non English majors.

Non English major is in an urgent need to improve translation competence in order to adapt to the needs of future development. Corpus and concordance software can help students improve the efficiency of translation. Based on the current situation, this study intends to have an empirical study via this platform of university English 
corpus on analyzing students' homework and functioning in teaching, trying to prove that the corpus-based translation teaching model will promote the translation competence, thus significantly improve English Comprehensive application ability.

\section{RESEARCH PROCEDURES AND DISCUSSION}

Thirty students are chosen from different departments to experience corpus-based translation teaching with the purpose of testing the role and effect of corpus in translation teaching .Teaching content and relevant information are displayed in table one.

TABLE I INFORMATION OF THE EXPERIMENT

\begin{tabular}{|c|c|}
\hline Teaching content & 1, C-E phrase translations 2, discourse translation \\
\hline Teaching period & two \\
\hline Class size & 30 students \\
\hline classroom & Multimedia classroom \\
\hline Teaching materials & materials from newspaper, magazines or literature originals \\
\hline $\begin{array}{c}\text { Translation } \\
\text { criterion }\end{array}$ & $\begin{array}{c}\text { faithful, smooth, elegance } \\
\text { dynamic equivalence }\end{array}$ \\
\hline $\begin{array}{l}\text { Teaching } \\
\text { procedures }\end{array}$ & $\begin{array}{ll}\text { 1, Present teaching materials in the form of PPT } \\
2, \quad \text { Analyze materials difficulties in groups(10 minutes) } \\
3, \quad \text { Translations of groups are displayed.(10minutes) } \\
4, \quad \text { Comparison and contrast of translations offered by each } \\
\text { group(10 分钟) } \\
\text { 6, Reference translations are presented by teachers. } \\
\end{array}$ \\
\hline $\begin{array}{l}\text { Discussion } \\
\text { Pattern }\end{array}$ & $\begin{array}{ll}1, & \text { Group members discussion } \\
2, & \text { Group representative discussion } \\
3, & \text { Teache-r student discussion } \\
\text { 4, } & \text { Discussion via corpora }\end{array}$ \\
\hline
\end{tabular}

\section{A. C-E phrase translation practice}

A phrase: Jimao Xin( in Chinese)

Jimao Xin produced in 1954 by the Shanghai film studio is known as the new China's classic of children film. Jimao Xin (A letter with a feather )in Chinese refers to the documents and mail that need rapid delivery. In many ancient poems, Jimao Xin is named A Feather Book which means an urgent document.

TABLE II STUdENTS' TRANSLATIONS OF JiMAO XIN

\begin{tabular}{|c|c|c|}
\hline $\begin{array}{c}\text { Source } \\
\text { language }\end{array}$ & $\begin{array}{l}\text { Analysis } \\
\downarrow \\
\text { Semantic } \\
\text { representation }\end{array}$ & Target language \\
\hline $\begin{array}{c}\text { JI MAO } \\
\text { XIN }\end{array}$ & synthesis & $\begin{array}{l}\text { 1. a message with a feather attached as a sign of urgency } \\
\text { 2.the letter with feathers } \\
\text { 3.the shepherd's message }\end{array}$ \\
\hline
\end{tabular}

Based on the translation principles put forward by English translator A F Tytler in 2010[12] (i.e. 1 Translation should give a complete transcript of the ideas of the original work. 2 The style and manner of writing should be of the same character with that of the original. 3.As smooth as the original and Yan Fu's statement of Three Translation standards: faithfulness, expressiveness and elegance and American translation theorist Eugene A Nida's "dynamic equivalence". An evaluation table has been developed as follows:
TABLE III TRANSLATION EVALUATION STANDARDS

\begin{tabular}{|c|c|c|c|c|c|}
\hline asp & theme & $\begin{array}{c}\text { Writing } \\
\text { style }\end{array}$ & $\begin{array}{l}\text { Languag } \\
\text { e style }\end{array}$ & $\begin{array}{c}\text { Language } \\
\text { fluency }\end{array}$ & $\begin{array}{l}\text { Languag } \\
\text { e } \\
\text { accuracy }\end{array}$ \\
\hline Perfect(the same) & A & A & A & A & A \\
\hline dynamic equivalence & B & B & B & B & B \\
\hline acceptable & C & C & C & C & C \\
\hline unacceptable & D & D & D & D & D \\
\hline
\end{tabular}

A reveals the complete equivalence between target and source language in all aspects. B means equivalence in some aspects.C refers to acceptable translation. D means unacceptable. Translation will be discussed from theme, writing style, language style,fluency and accuracy.

In the process of teaching, students fully express their views, discuss from aspects above and completed the analysis and evaluation of translation.

Discussion : JIMAOXIN theme can be shown from the translations in table 1 ?

TABLE IV THE EVALUATIONS OF TRANSLATION 1-

A MESSAGE WITH A FEA THER ATTACHED AS A SIGN OF UURGENCY

\begin{tabular}{|l|l|l|l|l|l|}
\hline level & theme & $\begin{array}{l}\text { Writing } \\
\text { style }\end{array}$ & $\begin{array}{l}\text { Language } \\
\text { style }\end{array}$ & $\begin{array}{l}\text { Language } \\
\text { fluency }\end{array}$ & $\begin{array}{l}\text { Language } \\
\text { accuracy }\end{array}$ \\
\hline Perfect(the same) & & & & & \\
\hline dynamic equivalence & & & & & \\
\hline acceptable & $C$ & & & & $C$ \\
\hline unacceptable & & & $D$ & $D$ & \\
\hline
\end{tabular}

TABLE V THE EVALUATIONS OF TRANSLATION 2-THE LETTER WITH FEATHERS

\begin{tabular}{|l|l|l|l|l|l|}
\hline level & $\begin{array}{l}\text { aspec } \\
\text { them }\end{array}$ & Writing & $\begin{array}{l}\text { Language } \\
\text { style }\end{array}$ & $\begin{array}{l}\text { Language } \\
\text { fluency }\end{array}$ & $\begin{array}{l}\text { Language } \\
\text { accuracy }\end{array}$ \\
\hline Perfect(the same) & & & & & \\
\hline dynamic equivalence & & & & & \\
\hline acceptable & & & & C & \\
\hline unacceptable & D & & D & & D \\
& & & & & \\
\hline
\end{tabular}

TABLE VI THE EVALUATIONS OF TRANSLATION 3 -THE SHEPHERD'S MESSAGE

\begin{tabular}{|l|l|l|l|l|l|}
\hline $\begin{array}{c}\text { level aspe } \\
\text { ct }\end{array}$ & theme & $\begin{array}{l}\text { Writing } \\
\text { style }\end{array}$ & $\begin{array}{l}\text { Language } \\
\text { style }\end{array}$ & $\begin{array}{l}\text { Language } \\
\text { fluency }\end{array}$ & $\begin{array}{l}\text { Language } \\
\text { accuracy }\end{array}$ \\
\hline Perfect(the same) & & & & & \\
\hline $\begin{array}{l}\text { dynamic } \\
\text { equivalence }\end{array}$ & & & & & \\
\hline acceptable & & & & C & \\
\hline unacceptable & D & & D & & D \\
\hline
\end{tabular}


It is shown from table4, table 5 and table6 above three translations are not accepted by readers. Then we go to discussion.

Discussion : Factors that should be considered in translation: How to translate? How can it be translated? How should it be translated?

How to solve the questions above? Can we locate answers via corpora?

Items containing feather and emergency message are searched. Results are as follows:

as light as a feather - Feather means light.

Birds of a feather flock together.-Feather implies the same. feather in one's cap-Feather means something proud.

feather one's own nest-Feather implies being selfish.

Fine feathers make fine birds-Feather implies good equipment.

It shows that feather in five phrases has nothing to with emergency.

Two sample sentences are as follows:

1 , We deemed the information to be credible, or would not have issued the emergency message.

2, The embassy passed along the notice in an emergency message for U.S. citizens.

"emergency message" is equivalent to the implication of Jimao Xin in ancient times. Therefore it conveys the theme of the original and easily acceptable to readers.

\section{B. C-E discourse translation practice}

This is the translation of a Chinese text.

Western imperialistic powers intensified invasion to China in terms of successive emerging of Concessions, garrisons, banks, factories and churches to impose more rigorous domination politically, economically ,militarily, and culturally. China was partitioned by the invasive powers of fierce loot. The Provisional Constitution of the Republic of China of modern democracy nature was enacted by Nanking Interim Government.

This discourse is adapted from museum commentary.

It is agreed on that theme, language style and language accuracy of the translation is unacceptable.Language fluency is relatively acceptable.With the help of BNC and COCA,the following questions are discussed.

Question 1: Is the expression of the invasive powers acceptable?By the search of corpora, we obtained 2416 tokens. It is discovered that invasive tends to appear with species, disease and organism.

Question 2: Is the expression of fierce loot acceptable?

By searching the corpora, only to find no solution for query. After fierce was entered respectively to search relevant instances or sample sentences, we obtained 5925 tokens. It can be found from the corpora that fierce often appear with the words such as battle, clash, combat, warrior, competition, fighting, opposition ,activism, affirmation. After loot was entered to search relevant instances or sample sentences, we obtained 726 tokens. Loot tends to emerge in the following expressions such as the war loot, the immense loot, leftover loot, buried loot, campaign loot, hard-earned loot. Therefore, the original Chinese text can be translated into China was looted by Western powers or China was partitioned by Western powers.
Question 3:Is the expression of intensify invasion is acceptable?

The search shows that no solution can be found. Popular collocations are as follows: intensify attacks, intensify the work, intensify the budget, intensify the links. Successive emerging show no solution for query in the corpora.

Therefore, the original can be translated into western powers had invaded China increasingly in the forms of concessions, garrisons, banks, factories and churches to impose more rigorous domination ...,

Question 4: Is the expression of democracy nature is acceptable?

The search results in BNC and COCA indicate there are no matching records. Yet nature of democracy has many matching records, which means nature of democracy is frequently used. While "democracy" means a system of government based on this belief, in which power is either held by elected representatives or directly by the people themselves( the Cambridge Advanced Learner's Dictionary \& Thesaurus (C) Cambridge University Press)[13]. So democracy itself implies a specific system, thus nature is unnecessary. The translation can be modified into "The Provisional Constitution of the Republic of China, which was characterized by democracy, enacted by Nanking Interim Government, ...,

\section{Translation test and analysis}

After similar practice of translation for a term, students attended translation test and interview. The results shows that students have greater enthusiasm than before in translation and $72 \%$ have done better than before. Some problems also appear. For example, students rely too much on the corpus thus they are very careless when translating. Difficulty index of translation tasks are not under control, which tend to scare students. Some students are not proficient in employing corpus, which needs attention of teachers. These are to be resolved in the future teaching research.

\section{CONCLUSIONS}

In translation teaching, teachers guide students to identify word frequency and proper collocation via corpus lexically, grammatically, semantically and pragmatically by comparing different translation versions or contrasting the original text and the target text thus to achieve a successful communication between authors and potential readers.

In a word, compared with the traditional translation teaching mode, the corpus-based translation teaching can improve learners' awareness of corpus application and employ diversity of language in the learning process, stimulating learners to explore problems in translation. Learners' initiative and autonomy have also been developed fully. In the short run, learners' translation competence and learning ability are improved. In the long run, learners' research ability is also improved.

Students as learners are supposed to be trained to recognize the role of the corpus in translation and the importance of translation. Corpus helps to produce better translation but does not guarantee the quality translation. 
A good translation depends on many factors. The teacher first demonstrates how to apply corpus in translating lecture in the multimedia autonomous learning center in order to help students familiarize corpus and solve problems that appear. In addition, interactive online platform is supposed to create for students to discuss translating.

Besides, students' translation assignment can work as archive for further research and learning. Teachers and students form a fruitful relationship during the process of establishing translation archive corpus. Translation problems and characteristics of students are analyzed through collection thus regularities are summarized.

This corpus-based translation teaching is like workshop translation, which United States of America focuses on in its translation teaching. Mutual participation and cooperation occur in such classroom interaction. That fulfills the goal of teaching reform.

\section{ACKNOWLEDGMENT}

My gratitude goes to education department of Hubei Province for its financial support and to Professor Xiang Rong for her help with data collection and eventual completion of the paper. This paper is one of researches of 2014 Teaching and Research Project for Hubei Province. The Project Number: 2014303. It is also one of researches of 2013 Teaching and Research Project for Wuhan Municipal Universities. The Project Number: 2013017.

\section{REFERENCES}

[1] Baker,M.Corpora in Translation Studies: An Overview and Some Suggestions for Future Research. Target Vo. 1 7, 1995: 231.
[2] Baker(1998), M. Routledge Encycopedia of Translation Studies London and New York : Rout ledge , 1998

[3] Laviosa, S. 1997. How comparable can comparable corpora be. Target 9, 2: 289-319.

1998a. The corpus- based approach: A new paradigm in translation studies. Meta 43, 4: 474-9.

1998b. Core patterns of lexical use in a comparable corpus of English narrative prose. Meta 43, 4: $557-70$.

[4] Kenny, D. 2001. Creatures of habit? What translators usually do with words. Meta 43, 4: 515-23.

[5] Bowker, Towards a methodology for a corpus- based approach to translation evaluation. Meta 46, 2001, 2: 345-64.

[6] Wang Kefei et al. Corpus Translation Studies - a new paradigm of research. Foreign Languages In China 2006, 3:8-9..

Wang Kefei A corpus- based Study on the Lexical Characteristics of Chinese . Chinese Translators Journal , 2008 ,6:.16-21

Wang Kefei A Contrastive Corpus-based Study of English and Chinese Language Features . Foreign Language Research, 2009,1:102-105

[7] Luo Xuanmin. Corpus and Translation Studies . Foreign Language and their Teaching, 2005 ,12:52-56.

[8] Hu Kaibao et al. Corpus and Translation Studies: trends and issues . foreign language, 2007, 5:64-69.

[9] Zhang Meifang. Study of Translator's Style via Corpus. Journal of PLA University of Foreign Languages, 2002,3:54-57.

[10] Xu Wensheng, Zhang Bairan. A Comparative Study on the Causal Conjunction based on English and Chinese Classic Works Corpus . Foreign Language Teaching and Research, 2006, 4:292-296.

[11] Hu Xianyao. Research on the Lexical Characteristics of the Chinese Translation Novels Based on Corpus . Foreign Language Teaching and Research, 2007,3.214-220.

[12] Alexander Fraser Tytler(2010). Essay on the principles of translation Gale Ecco, Print Editions 2010

[13] The Cambridge Advanced Learner's Dictionary \& Thesaurus (C) Cambridge University Press 